\title{
DIVERSITY AND ABUNDANCE TRENDS OF BENTHIC FORAMINIFERA FROM THE SOUTHERN PART OF THE IRAKLION BASIN, CENTRAL CRETE
}

\author{
H. Drinia, A. Antonarakou and N. Tsaparas \\ National and Kapodistrian University of Athens, Dept. of Geology, Section of Hist. Geology- \\ Paleontology, Panepistimiopolis, 15784 Athens, Greece, cntrinia@geol.uoa.gr, \\ aantonar@geol.uoa.gr,ntsapar@geol.uoa.gr
}

\begin{abstract}
Benthic foraminiferai fossil assemblages of the Roufas Section, southern Iraklion Basin, central Crete, were analyzed for the first time. Taxonomic and quantitative analyses were made in order to obtain paleoenvironmental (physical as well biological) information. A data set has been subjected to R- and Q-mode cluster analyses in order to demonstrate the linkage between taxa distribution and paleoenvironmental gradients. Our results suggest that oxygenation and trophic conditions of the near-surface sediments are the most important factors that control the community structure of the benthic foraminiferal fauna. The application of the oxygen transfer function - based on the use of benthic foraminiferal taxa from oxyphilic habitats - to the benthic faunas of the Roufas Section, allows the reconstruction of the oxygen contents of the bottom waters. Apart from the middle part of the section, no severe ciisturbances are recorded, pointing to the fact that we are dealing with an overall rather well ventilated water column during most of the part of the sequence.
\end{abstract}

\section{INTRODUCTION}

This study is part of a larger scoped investigation on the biotic changes in the Late Pliocene of the Roufas Section, in the Iraklion Basin, in Central Crete. In this work, the succession of paleoenvironments and benthic foraminiferal assemblages are analyzed. The main objectives of the study are: 1) the determination of the foraminiferal biofacies and biofacies shifts related to environmental changes and 2) the documentation of how benthic foraminiferal assemblages of the Late Pliocene record from the Eastern Mediterranean develop under fluctuating bottom water oxygen.

\section{MATERIAL AND METHODS}

\subsection{Study area}

Roufas Section, approximately $28 \mathrm{~m}$ thick, constitutes part of the Iraklion Basin (sensu Meulenkamp et al., 1994), which is located in Central Crete (Fig. 1). It is mainly composed, in its basal part by marly limestones and sands, followed by marls and silty marls. For this study, a total number of 8 samples were collected from the silty marls. The biostratigraphic analysis of the studied area has been carried out on the basis of the planktonic foraminifera fauna and revealed that the studied deposits belong to the Biozone of Globorotalia crassaformis (interval IV) of Spaak (1983) and MPL4 (Cita 1975).

\subsection{Micropaleontological analysis}

The benthic foraminiferal quantitative analyses were carried out on the total assemblage (>125 $\mathrm{mm}$ fraction) and about 300 individuals were counted from subsamples obtained by a microsplitter. Assemblages were then sorted, identified and counted and the data compiled on to an Excel spreadsheet. Taxa at the species or genus level that amounted to $<1 \%$ averaged across the data set were removed from the data matrix so that statistical analyses of the data were based on the common and abundant taxa. On the basis of the faunal counts, we calculated values $H(s)$ for diversity using the Shannon-Wiener information equation (Buzas \& Gibson 1969), Species Richness 
(number of species), Equitability (Buzas \& Gibson 1969), Dominance and the Fischer $\alpha$-index (Fisher et al. 1943). Raw data of microfossils were then transformed into percentages over the total abundance and percentage abundance curves were plotted. Species with phylogenetic affinities and similar environmental significance were also grouped to better interpret distribution patterns.

\section{ROUFAS SECTION}

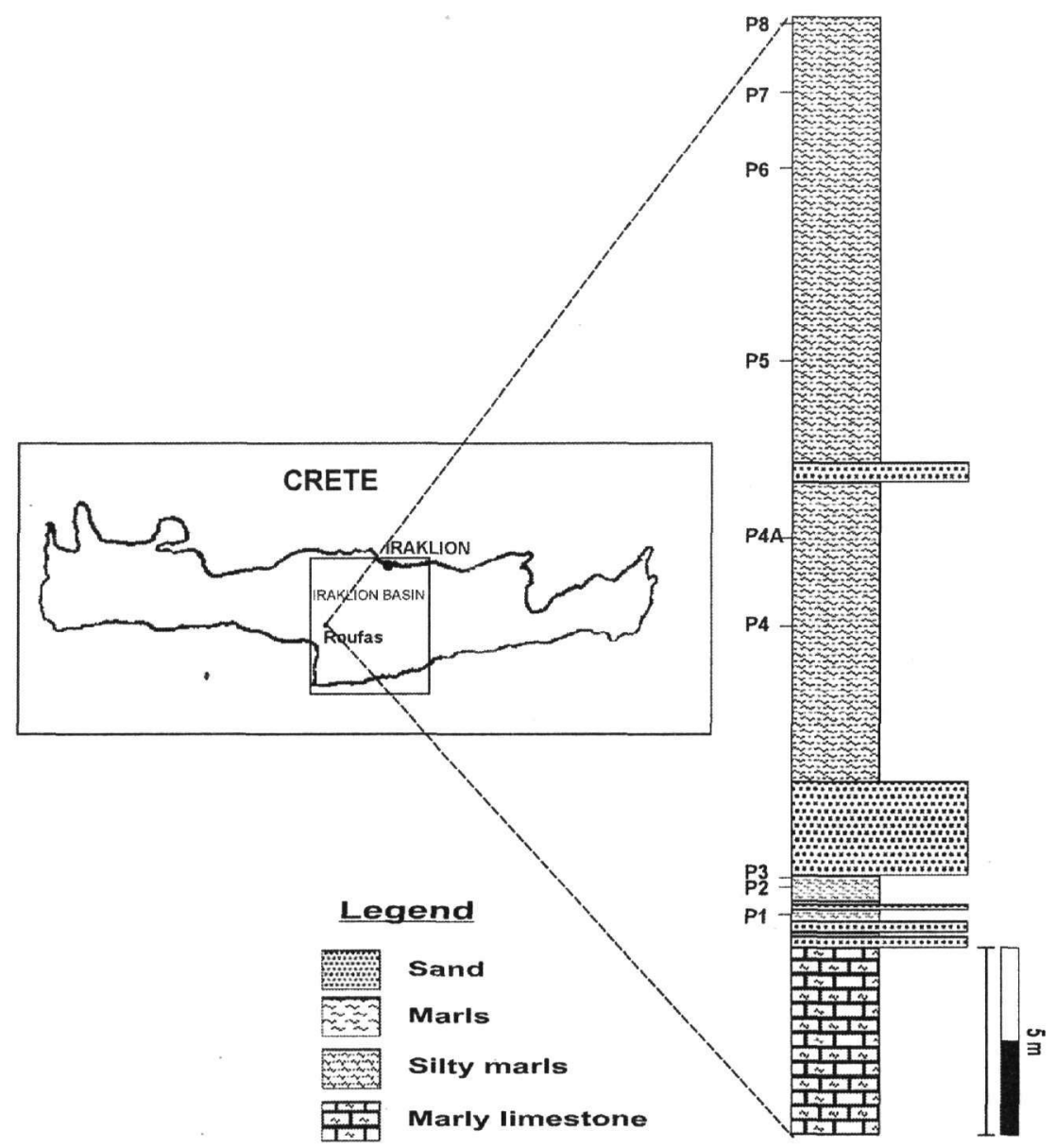

Fig. 1. Lithostratigraphical column of Roufas Section.

Additionally, $\mathrm{P} / \mathrm{B}$ ratios expressed as $100^{*} \mathrm{P} /(\mathrm{P}+\mathrm{B})$, i.e. the percentages of planktic foraminifera in the total foraminiferal assemblages, and infauna versus epifauna were used as indicators of paleobathymetry, paleoproductivity and upwelling. Paleobathymetry was also calculated for each sample by introducing P/B ratios, based on epifaunal species, in the equation of v.d. Zwaan et al. (1990). Finally, we applied the oxygen transfer function of van der Zwaan et al. (op. cit.) to the benthic faunas of the Roufas Section, according to the formula:

\section{[Oxygen content $\mu \mathrm{Mol} / \mathrm{lt}]=7.9602+5.95$ [\%oxyphilic taxa]}

We selected a group of calcareous oxyphilic species (Table I) in order to reconstruct the oxygen contents of the bottom waters. Agglutinated species were omitted because of the evident fragility and rather low preservation potential of a number of them.

For paleoenvironmental reconstructions, multivariate analyses (Q-mode and R-mode cluster analysis) were performed on benthic foraminiferal species relative abundance data. Cluster analysis was carried out on a reduced data set to examine the species associations using PAST (1.19) 
package (Hammer et al. 2001), with the purpose of describing the major trends in benthic faunal development. The 20 highest ranked species were selected on the basis of a relative abundance of $2 \%$ or more in at least one sample and occurrence in at least three samples. The level of similarity between samples or species is the expression of assumed homogeneity of environmental conditions.

Table I: Species used as input for the transfer function calculating bottom-water oxygenation

\begin{tabular}{|l|l|}
\hline \multicolumn{2}{|c|}{ Oxyphilic taxa } \\
\hline Ammonia beccarii & Gyroidina soldanii \\
\hline Anomalinoides helicinus & Gobocassidulina. subglobosa \\
\hline Bolivina pseudoplicata & Lenticulina sp. \\
\hline Cassidulina carinata & Oridorsalis stellatus \\
\hline Cibicides spp. & Oridorsalis umbonatus \\
\hline Cibicidoides spp. & Planulina ariminensis \\
\hline Cassidulina laevigata & Quinqueloculina sp. \\
\hline Gyroidinoides neosoldanii & Reusella. spinulosa \\
\hline Gavelinopsis praegeri & \\
\hline
\end{tabular}

\section{RESULTS}

\subsection{Faunal pattern}

For the most part, Roufas Section is characterized by epifauna, epiphytic species such as Asterigerinata planorbis, Elphidium sp., Cibicides sp. and Hanzawaia boueana (Fig. 2), indicating the predominance of stable marine conditions, with high levels of oxygenation and relatively high salinity. The lower part of the section is characterized by the dominance of Anomalinoides sp., Bulimina aculeata, Bolivina pseudoplicata, B. spathulata and Uvigerina bononiensis, a peculiar oligotaxic assemblage dominated by opportunistic and tolerant taxa. The nature of the environmental stress in this part of the sequence is lent by the high percentage of $B$. pseudoplicata, which has been reported as an open marine mud-dweller, confined to relatively shallow depths (Phleger 1951, Murray 1971). It has never been reported from hypersaline waters, but Boltovskoy \& Lena (1971) report it from hypo-saline waters. It may be concluded that B. pseudoplicata exhibits a rather irregular ecological pattern through time and a tolerance to low salinity might exist.

At about $16,1 \mathrm{~m}$ (in the middle part of the sequence), the epifaunal forms decrease abruptly in relative abundance as the infaunal morphogroup increases in abundance. Keller (1988), Speijer \& van der Zwaan (1996) and Kouwenhoven (2000) explained such unusual dominance by assuming low-oxygen conditions, which may have been caused by changes in circulation. Indeed, $U$. bononiensis, B. aculeata and B. spathulata, which predominate, are thought to be indicative of extremely stagnant bottom waters (van der Zwaan 1982, Jonkers 1984, Katz \& Thunell 1984, van der Zwaan \& Gudjonsson 1986). This may lead to the conclusion that stagnant conditions became more severe in this part of the succession.

The uppermost part is composed almost entirely of epifaunal species $(80 \%)$. This part reflects a drastic collapse in food supply to the seafloor, with assemblages dominated by epifaunal detritus and suspension feeders. Genera that prefer a high nutrient supply such as $U$. bononiensis disappeared. The shortage of food resulted in complete oxidation or consumption of all organic matter before it could be buried in the sediment, so that no food remained for infaunal taxa. The common occurrence of Bolivina antiqua however, suggests that some food particles were available at the sediment/water interface.

\subsection{Multivariate analysis}

The dataset originally containing 90 taxa was condensed to 20 taxa and (supra-) generic categories. This condensed dataset was subjected to R-and Q-mode cluster analyses.

The R-mode cluster analysis resulted in the dendrogram shown in Fig. 3A. The fauna can be divided into three groups. Cluster I contains taxa indicative of normal marine conditions and predominates throughout the succession (Fig. 3B). The diverse calcareous foraminiferal fauna contained in 
this cluster is typical of a highly-oxygenated realm and a well-aerated substrate. Moreover, the species belonging to Cluster I are all considered to be tolerant to raised salinities (A. planorbis, $H$. boueana, $R$. spinulosa, Lenticulina). Elphidium sp. and C. lobatulus have a tolerance to hypo-saline conditions and wide tolerance to salinity fluctuations. Murray $(1973,1976)$ and Boltovskoy (1976) mention these species as important constituents of the living fauna of hypo- to hypersaline lagoons, where they live mainly on vegetation.

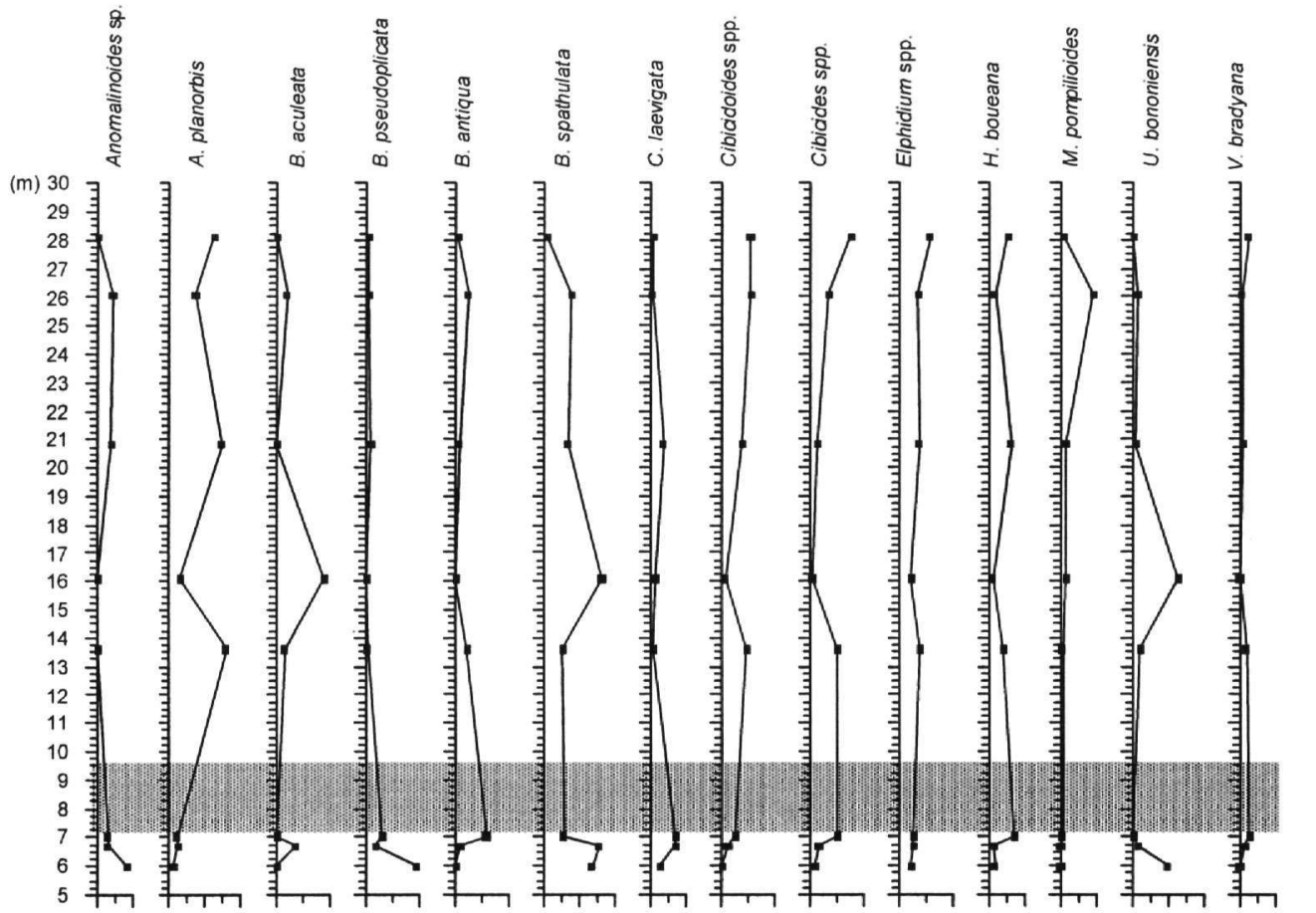

$\begin{array}{lllllllllllllllllllllllllllllllll} & 0 & 10 & 0 & 20 & 40 & 0 & 20 & 0 & 20 & 0 & 20 & 0 & 20 & 40 & 0 & 10 & 0 & 20 & 0 & 20 & 0 & 20 & 0 & 10 & 0 & 10 & 0 & 20 & 40 & 0 & 10 & (\%)\end{array}$ Fig. 2. Relative frequency curves of selected benthic foraminifera from Roufas Section. The dashed zone indicates the sandstone level.

Cluster Ila is mainly composed of species which thrives in moderate environmental stress. It is present throughout the section but in very low percentages, apart from the earlier part of the succession where it shows its peak abundance (Fig.3B). The dominant species, B. pseudoplicata, is described in environments where water salinity is slightly brackish to hypersaline, with salinity ranging from 33 to $40 \%$ (e.g. Murray 1991, Debenay et al. 2001a, 2001b). Other author described it in salinity amplitude from 1 to more than 22\%o (Brasier 1981). Opinions about its habitat requirements vary from mud-dwelling and low-oxygen tolerant (van der Zwaan 1982) to epiphytic in well oxygenated environments (Jonkers 1984). According to Verhallen (1991) this is a mud-dwelling species indicative of normal marine conditions. Cassidulina laevigata is a stress-tolerant species which thrives under unstable conditions. In the Mediterranean Sea, it requires eutrophic bottom conditions (De Rijk et al. 2000). Melonis padanum is especially abundant in areas with high food supply, whereas Anomalinoides sp. thrives in intervals rich in organic matter. These relationships are interpreted to indicate that the fauna consisting of B. pseudoplicata, C. laevigata, M. padanum and Anomalinoides sp. represents deposition at middle to outer neritic water depths in association with the deposition of abundant organic matter.

Cluster Ilb, although present throughout the section, shows high abundance values in the middle part of the succession $(16,1 \mathrm{~m})$ where it seems to increase at the expense of Cluster I (Fig. 3B). It is composed of $B$. spathulata, $U$. bononiensis and $B$. aculeata. Bolivina spathulata is known to survive in oxygen deficient environments (Murray 1991). It is often dominant in the oxygen- 
minimum zone or in the upwelling zones (e.g. Phleger \& Soutar 1973, Poag 1984, Mullins et al. 1985). Bulimina aculeata occurs in high abundances beneath areas of continuous high food productivity and resulting low oxygen conditions (Gupta 1997, Kawagata 2001). Uvigerina bononiensis was able to live in waters with a severely reduced content (Jonkers 1984).

A)

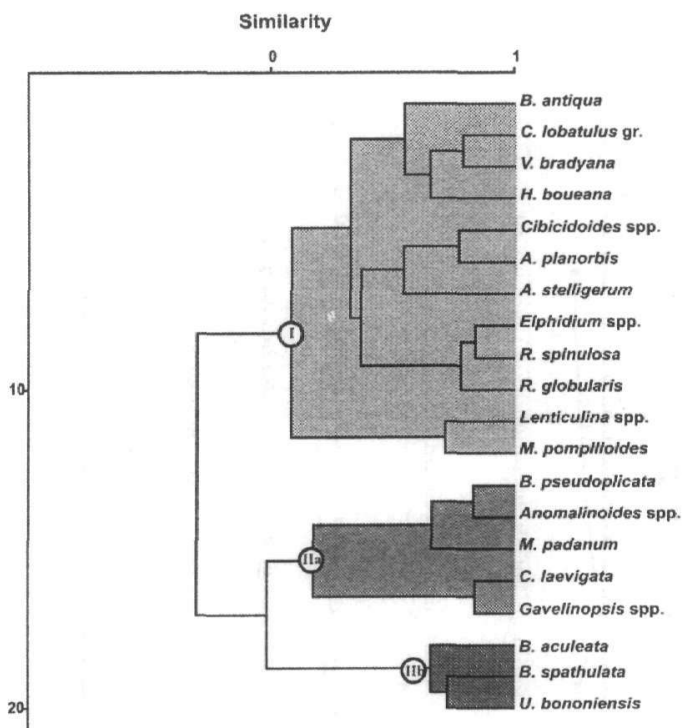

B)

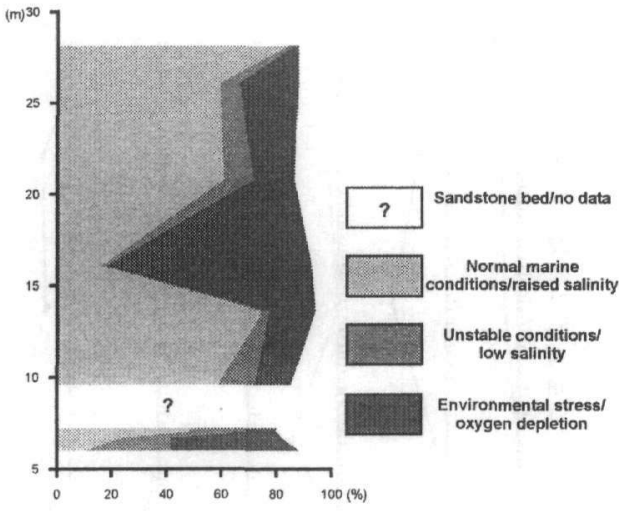

Fig. 3. (A) Dendrogram resulting from hierarchical R-mode cluster analysis. (B) The record of benthic foraminifera clusters percentage.

Therefore Cluster Ilb includes species living in stagnant environments with low amount of dissolved oxygen of the bottom waters and a relatively large nutrient availability.

Q-mode clustering of the percentage contribution of the 20 species to each of 8 samples, produced two main clusters and one outlier, each one corresponding to groups of samples containing similar benthic foraminiferal assemblage. The dendrogram (Fig. 4) groups the samples into clusters characterized by the dominance of certain species. Each cluster may be referred to different paleoenvirornmental conditions. Therefore, B. spathulata assemblage covers the lowermost and middle part of the section and includes samples P1, P2 and P4A. It connotes ecological stress which is linked to the presence of low oxygen values in the bottom water (Murray 1991). Asterigerinata planorbis assemblage is well presented in the rest of the record including samples P4, P5, P6 and P7. It includes species that are indicative of normal marine conditions (van der Zwaan 1982, Jonkers 1984, Verhallen 1991). The outlier includes sample P3 which is characterized by the predominance of $B$. antiqua suggesting normal marine conditions with some food particles available at the sediment/water interface.

\subsection{Species Diversity and Dominance}

The general faunal characteristics expressed by the Fischer- $\alpha$ index, Shannon diversity and dominance show predictable patterns (Table II): high (low) diversity corresponds with low (high) dominance. Dominances range from $11,47 \%$ to $32,25 \%$, with highest dominances occurring in P4A and $\mathrm{P} 4$ levels where $B$. spathulata and $A$. planorbis predominate respectively. Such high dominance, low diversity faunas are not expected under oligotrophic, stress-free conditions (e.g. Kouwenhoven 2000). Intervals with high benthic diversity contain about 40-45 different taxa with dominances being on average between 11 to $25 \%$, reflecting lower levels of ecological stress and an oligotrophic stress-free environment.

It is well known that plankton/benthos ratio $\left(100^{*} \mathrm{P} / \mathrm{P}+\mathrm{B}\right)$, where $\mathrm{P}$ is the planktonic foraminifera and $\mathrm{B}$ is the benthic foraminifera, can be regarded as a measure of depth of deposition (e.g. 
Grimsdale \& van Morkhoven 1955, van der Zwaan et al. 1990), a paleoproductivity index (Berger \& Diester-Haass 1988, Herguera 1992) or as measure of preferential loss of planktonics by dissolution (e.g. Adelseck \& Berger 1975). Faunas, particularly those in the plankton, are numerically very high from 6 to $26,1 \mathrm{~m}$ of the record, in which there is planktonic/benthic ratio as high as $50 \%$, apart from $28,12 \mathrm{~m}$ level where the P/B ratio equals $15 \%$ (Fig.6A)

Similarity

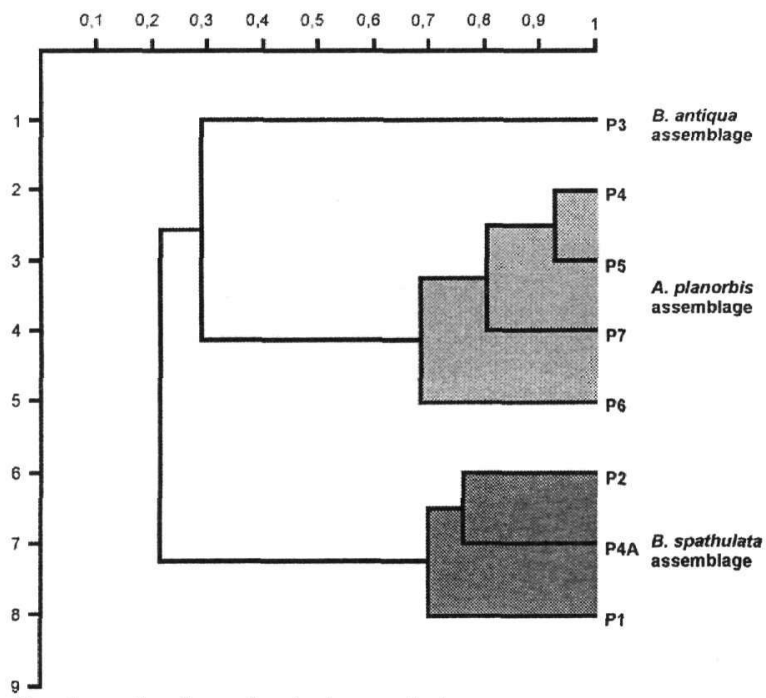

Fig. 4. Dendrogram resulting from the Q-mode cluster analysis.

Table II: Faunal parameters (Fischer-a, Dominance, Shannon diversity)

\begin{tabular}{|c|c|c|c|c|}
\hline SAMPLES & HEIGHT(m) & FISCHER- $\alpha$ & DOMINANCE & SHANNON \\
\hline P1 & 6 & 6,4 & 27,05 & 2,21 \\
\hline P2 & 6,7 & 37,71 & 30,7 & 3,28 \\
\hline P3 & 7,03 & 37,15 & 11,47 & 3,57 \\
\hline P4 & 13,6 & 15,36 & 31,89 & 2,46 \\
\hline P4A & 16,1 & 13,39 & 32,25 & 2,12 \\
\hline P5 & 20,8 & 23,72 & 28,99 & 2,88 \\
\hline P6 & 26,1 & 27,84 & 15,06 & 3,14 \\
\hline P7 & 28,12 & 14,32 & 25 & 2,72 \\
\hline
\end{tabular}

\subsection{P/B-Paleobathymetry}

The approximate water depth for the sediments from the Roufas Section is assessed by means of the plankton/benthos ratio. Therefore, we identify an inner shelf environment (values not exceeding $20 \%$ ), corresponding to $28,12 \mathrm{~m}$ (the uppermost part of the record), which yield the shallower assemblage, and a slope to outer shelf environment (values between 20-60\%):

Paleobathymetry was also calculated for each sample by introducing P/B ratios based on epifaunal species, in the equation of van der Zwaan et al. (1990). Based on water depth zonation of Bremer et al. (1980) and van Morkhoven et al. (1986), the depositional depth of the section varies from around 70 to $730 \mathrm{~m}$, indicating an environment in the middle neritic to middle bathyal zone (Fig.6B). The abrupt increase in water depth at $16,1 \mathrm{~m}$ is associated with high productivity. 

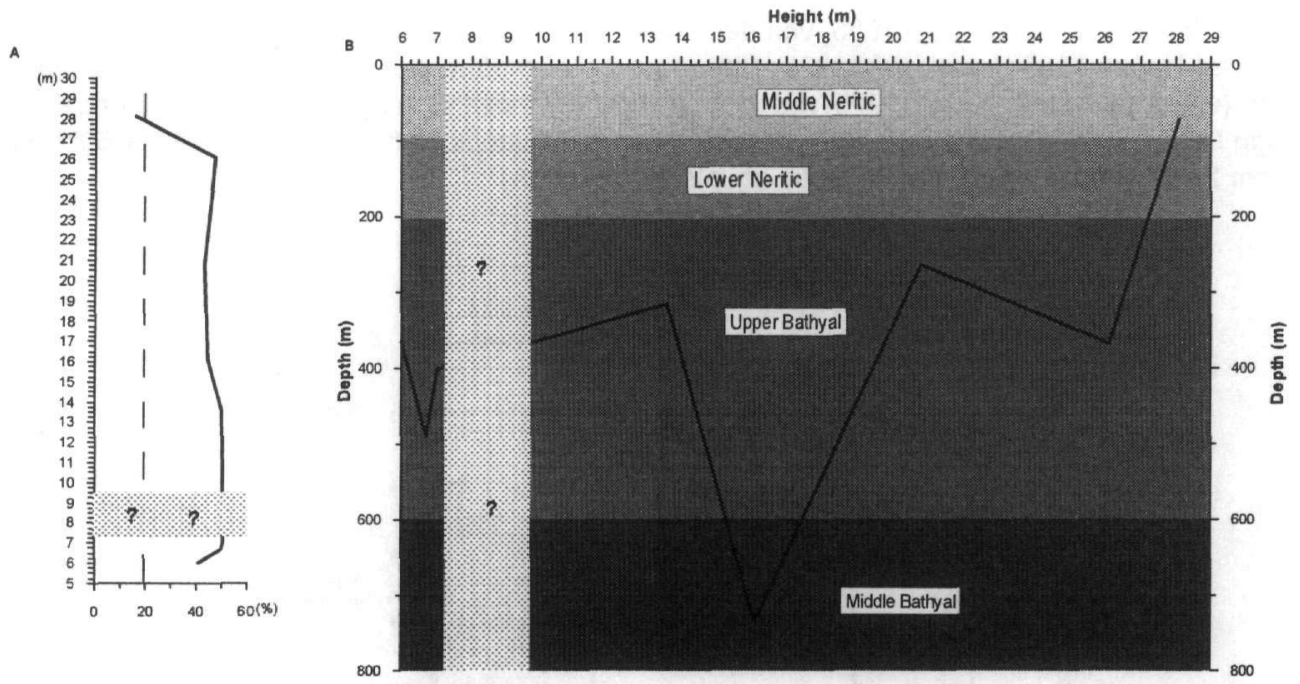

Fig. 6. (A) P/B ratio distributional pattern of the studied succession of the Roufas Section. (B) Depth reconstruction of the studied sequence of the Roufas Section.

\subsection{Infauna versus Epifauna - Paleoproductivity}

In order to evaluate the preferred microhabitat, species of total assemblages were divided in two groups, epifauna-shallow infauna and deep infauna (e.g. Jorissen et al. 1995), considering only the species with frequencies greater than $2 \%$. The species that generally live within the top two centimeters of surficial sediment were attributed to the former group, those living deeper were assigned to the latter group (Buzas et al. 1993, Corliss 1985, Corliss \& Chen 1988, Barmawidjaja et al. 1992). A plot of their relative abundance (Fig.7) shows the epifaunal component dominating the benthic community except in one interval (at $16,1 \mathrm{~m}$ ), where the infaunal component rises more significantly. The infauna flourishes in quiet environments well supplied with organic carbon as beneath oxygen-poor waters where the trophic profile is high (Gooday 1986). Their high abundances usually signal eutrophication in the water column. These conditions are more typical of colder or deeper waters and may occur at shallower sites with upwelling influence. Other mechanisms that may produce a similar effect include large-scale runoff which produces a brackish water lid and ultimately a high nutrient level. As the composition of the fauna (B. spathulata, B. aculeata, $U$. bononiensis), in this part of the record, is indicative of extremely stagnant bottom waters (lower amount of dissolved oxygen and relatively large nutrient availability), the origin of this event is postulated to be associated with enhanced fresh-water inputs. Enhanced river run-off into the Roufas basin created the stratification of the water column leading to a severe decrease in the ventilation of the subsurface waters.

Together with the predominance of the infauna, there is a planktonic/benthic ratio as high as $85 \%$ (based on epifauna). According to Berger \& Diester-Haass (1988), high productivity is commonly associated with a high planktonic/benthic ratio.

\subsection{Oxygen-content}

The result of the oxygen transfer function as applied to data from the Roufas Section is presented in Fig. 8. In this figure we show the calculated oxygen content at the sediment-water interface. The reconstructed oxygen record represents the variation of the oxygen contents at the sediment-water interface, and suggests that the actual concentrations were moderate (ranging from 100 to $200 \mu \mathrm{Mol} / \mathrm{t}$. At $16,1 \mathrm{~m}$, the oxygen content reaches its lowest value, around $40 \mu \mathrm{Mol} / \mathrm{tt}(\sim 0,9$ $\mathrm{ml} / \mathrm{tt}$ ), which coincides with the peak occurrences of the Bolivinids/Buliminids group and the Uvigerinids. This drop of oxygen levels is followed by a gradual increase until the top of the section. This trend is in line with the pattern in frequency of the Bolivinids/Buliminids group and the increasing trend of the epifauna group. 
Epifauna vs Infauna

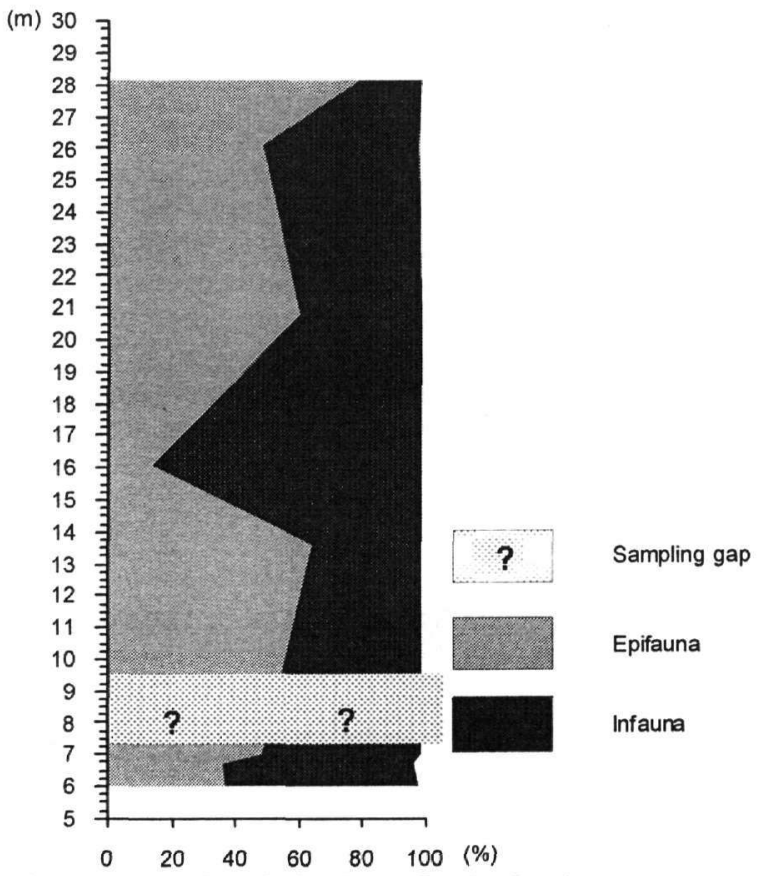

Fig. 7. Epifaunal versus infaunal benthic foraminifera in the Roufas Section.

Oxygen content

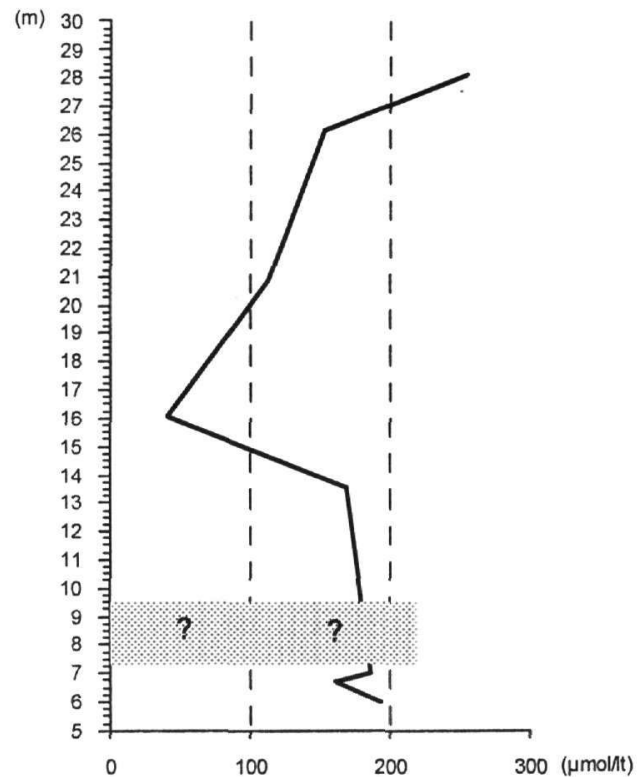

Fig. 8. Plot of the bottom-water oxygen content distribution, reconstructed with the transfer function. 
Roufas Section is characterized by a highly diverse and epifaunal as well as infaunal morphogroups indicative of normal marine conditions. These morphogroups are typical for outer neritic-middle bathyal marine environments with moderate primary productivity and a flux of organic detritus that is sufficient to sustain infaunal bottom-dwellers. The most important factors for the foraminiferal distribution were oxygenation and food availability. The bottom waters were well aerated apart from a conspicuous drop in oxygen content in the middle part of the sequence leading to extremely stagnant bottom waters. The temporal increase in the proportion of infaunal benthic foraminifera reveals one time interval of reduced bottom-water oxygenation and relatively large nutrient availability. The origin of this low-oxygen event might be associated with changes in the humidity of the borderlands and corresponding fresh-water inputs. Enhanced river run-off into the Roufas basin probably triggered high productivity and enhanced fluxes of organic carbon to the sea floor. Simultaneously, the stratification of the water column caused a severe decrease in the ventilation of the subsurface waters.

\section{ACKNOWLEDGEMENT}

The authors would like to thank loanna Borbotsialou for carrying out the laboratory work. Financial support for this research was provided by the Research Project 70/4/4511 of the University of Athens.

\section{REFERENCES}

Barmawidjaja, D.M., Jorissen, F.J., Puskaric, S. and Van der Zwaan, G.J., 1992. Microhabitat selection of benthic foaraminifera in the northern Adriatic Sea. J. Foram. Res., 22, 297-317.

Berger, W.H. and Diester-Haass, L., 1988. Paleoproductivity: the benthic/planktonic ratio in foraminifera as productivity index. Marine Geology, 81, 15-25.

Boltovskoy, E.,1976. Distribution of Recent foraminifera of the South American region. In: Hedley, R. H. \& Adams, C. G. (eds.), Foraminifera, 2: 171-236, Academic Press, London.

Boltovskoy, E. and Lena, H., 1971. The Foraminifera (except family Allogromiidae) which dwell in fresh water. J. Foram. Res., 1(2), 71-76.

Brasier, M.D., 1981. Microfossil transport in the tidal Humber basin. In: Neale and Brasier (Editors), Microfossils from recent and fossil shelf seas. Ellis Horwood Limited, Chichester, England, pp. 314-322.

Bremer, M.L., Briskin, M. and Berggren, W.A., 1980. Quantitative paleobathymetry and paleoecology of the Late Pliocene-Early Pleistocene foraminifera of Le Castella (Calabria, Italy). Journal of Foraminiferal Research, 10, 1-30.

Buzas, M.A. and Gibson, T.G., 1969. Species diversity: Benthonic foraminifera in western North Atlantic. Science, $163,72-75$.

Cita, M.B., 1975. Planktonic foraminiferal biozonation of Mediterranean Pliocene deep sea record. A revision. Rivista Italiana de Paleontologia e Stratigrafia, 81, 527-544.

Corliss, B.H., 1985. Microhabitats of benthic foraminifera within deep-sea sediments. Nature, 314, 435-438.

Corliss, B.H. and Chen, C., 1988. Morphotype patterns of Norvegian Sea deep-sea benthic foraminifera and ecological implications. Geology, 16, 716-719.

De Rijk, S., Troelstra, S.R. and Rohling, E.J., 1999. Benthic foraminiferal distribution in the Mediterranean Sea. Journal of Foraminifera Research, 29, 93-103.

Debenay, J.-P., Guillou, J.-J., Tsakiridis, E. and de Casamajor, M.-N., 2001a. Bioindicateurs d'impact dans les ports et les estuaires : les foraminiferes. Revue francaise de Genie Civil, 5, 1105-1122.

Debenay, J.-P., Tsakiridis, E., Soulard, R. and Grossel, H., 2001b. Factors determining the distribution of foraminiferal assemblages in Port Joinville Harbor (lle d'Yeu, France): the influence of pollution. Mar. Micropaleontol., 43,75-118.

Fisher, R.A., Corbet, A.S. and Williams C.B., 1943. The relationship between the number of species and the number of individuals in a random sample of an animal population. Journal of Animal Ecology, 12, 42-58.

Gooday, A.J.,1986. Meiofaunal foraminiferans from the bathyal Porcupine Seabight (northeast Atlantic): size structure, standing stock, taxonomic composition, species diversity and vertical distribution in the sediment. Deep Sea Res., 33, 1345-1373. 
Grimsdale, T.F. and Van Morkhoven, F.P.C.M., 1955. The ratio between pelagic and benthonic foraminifera as a means of estimating depth of deposition of sedimentary rocks. Proceedings of World Petroleum Congress, 4th, Rome. Sect. 1/D4, 473-491.

Gupta, A.K., 1997. Paleoceanographic and paleoclimatic history of the Somali Basin during the PliocenePleistocene: Multivariate analyses of benthic foraminifera from DSDP Site 241 (Leg 25). J. Foram. Res., 27, 196-208.

Hammer, O., Harper, D.A.T. and Ryan, P.D., 2001. PAST-PAlaeontological Statistics software package for education and data analysis. Palaeontologia Electronica.

Herguera, J.C., 1992. Deep-sea benthic foraminifera and biogenic opal: Glacial to postglacial productivity changes in the western equatorial Pacific. Marine Micropalontology, 19, 79-88.

Jonkers, H.A., 1984. Pliocene benthonic foraminifera from homogeneous and laminated marls on Crete, Utrecht Micropaleontological Bulletin, 31,179pp.

Jorissen, F.J., De Stigter, H.C. and Widmark, J.G.V., 1995. A conceptual model explaining benthic foraminiferal microhabitats. Mar. Micropaleontol., 26, 3-15.

Katz, M.E. and Thunnell, R.C., 1984. Benthic foraminiferal biofacies associated with Middle Miocene to Early Pliocene oxygen-deficient conditions in the eastern Mediterranean. Journal of Foraminiferal Research, 14,187-202.

Kawagata, S., 2001. Tasman Front shifts and associated palaeocenographic changes during the last 250,000 years: foraminiferal evidence from the Lord Howe Rise. Marine Micropalaeontology, 41, 167-191.

Keller, G., 1988a. Biotic turnover in benthic foraminifera across the Cretaceous/Tertiary boundary at El Kef, Tunisia. Palaeogeography, Palaeoclimatology, Palaeoecology, 66, 153-171.

Kouwenhover, T.J., 2000. Survival under stress: benthic foraminiferal patterns and Cenozoic biotic crises. Geologica Ultraiectina 186, 206 pp.,

Meulenkamp, J.E., Van Der Zwaan, G.J. and Van Wamel, W.A., 1994. On late Miocene to Recent vertical motions in the Cretan segment of the Hellenic arc. Tectonophysics, 234, 53-72.

Mullins, H.T., Thompson, J.B., McDougall, K. and Vercoutere, T.L., 1985. Oxygen minimum zone edge effects: evidence from the central California coastal upwelling system. Geology, 13, 491-494.

Murray, J.W. 1971. An Atlas of British Recent Foraminiferids. Heinemann Educational Books, London.

Murray, J. W., 1973. Distribution and Ecology of Living Benthic Foraminiferids. Cran, Russak and Co., New York, $274 \mathrm{pp}$.

Murray, J.W., 1976. Comparative studies of living and dead benthic foraminiferal distributions. In: Foraminifera, vol. 2, edited by R.H. Hedley and C.G. Adams, 45-109, Academic Press, London, New York, San Francisco.

Murray, J.W., 1991. Ecology and paleoecology of Benthonic Foraminifera. Longman Scientific and Technical, London, 274pp.

Phleger, F.B., 1951. Ecology of foraminifera, northwest Gulf of Mexico, part 1: foraminifera distribution. Geological Society of America, Memoir, 46, 1-88.

Phleger F.B. and. Soutar, A., 1973. Production of benthic foraminifera in three east Pacific minima. Micropaleontol., 19, 110-115.

Poag, C.W., 1984. Distribution and ecology of deep-water benthic foraminifera in the Gulf of Mexico. Palaeogeography, Palaeoclimatology, Palaeoecology, 48, 25-37.

Spaak, P., 1983. Accurency in correlation and ecological aspects of the planktonic foraminifera zonation of the Mediterranean Pliocene. Utrecht Micropaleontological Bulletin, 28, 160pp.

Speijer, R.P. and van der Żwaan, G.J., 1996. Extinction and survivorship of southern Tethyan benthic foraminifera across the Cretaceous/Palaeogene boundary. In: M.B. Hart (Ed.), Biotic Recovery from Mass Extinction Events. Geological Society Special Publication 102, 343-371

Van Der Zwaan, G.J., 1982. Paleoecology of late Miocene Mediterranean foraminifera. Utrecht Micropaleontogical Bulletin, 25, 1-205.

Van der Zwaan, G.J. and Gufjonsson, L., 1986. Middle Miocene-Pliocene stable isotope stratigraphy and paleoceanography of the Mediterranean. Mar. Micropaleontol., 10, 71-90.

Van Der Zwaan, G.J., F.J. Jorissen and De Stigter, H.C., 1990. The depth dependency of planktonic/benthic foraminiferal ratios: Constraints and applications. Marine Geology, 95, 1-16.

Van Der Zwaan, G.J., Almogi-Labin, A., Jannink, N.T., Duijnstee, I.A.P. and Jorissen, F.J. (subm.). Apparent oxyphilic benthic foraminifera: a new proxy in paleoceanography for quantitative reconstruction of oxygen content.

Van Morkhoven, F.P.C.M., Berggren, W.A. and Edwards, A.S., 1986. Cenozoic cosmopolitan deep-water benthic foraminifera. Bull. Cent. Rech. Explor.-Prod. Elf-Aquitaine, Mem., 11,1-412.

Verhallen, P.J.J.M., 1991. Late Pleistocene to early Pleistocene Mediterranean mud-dwellind foraminifera; influence of a changing environment on community structure and evolution. Utrecht Micropaleontological Bulletin, 40: 219pp. 